\title{
Erratum to: Structure of a self-assembled network made of polymeric worm-like micelles
}

\author{
Wissam Moussa ${ }^{1}$
}

Published online: 7 September 2016

(C) Springer-Verlag Berlin Heidelberg 2016

\section{Erratum to: Polym. Bull. (2016) 73:2689-2705}

DOI 10.1007/s00289-016-1615-5

This article was submitted without the knowledge of C. Chassenieux, L. Benyahia, O. Colombani and T. Nicolai. They should therefore not be listed as co-authors.

The online version of the original article can be found under doi:10.1007/s00289-016-1615-5.

Wissam Moussa

wissam_202@hotmail.com

1 IMMM UMR CNRS 6283 Département Polymères, Colloïdes, Interfaces, PRES LUNAM, Université du Maine, Avenue O. Messiaen, 72085 Lemans Cedex 9, France 